\title{
Principals' Narratives about Leading Schools during the COVID-19 crisis in South Africa
}

\author{
Emil Bosch
}

ORCID iD: https://orcid.org/0000-0001-5749-6017

\section{Jan Heystek}

ORCID iD: https://orcid.org/0000-0001-7695-5047

\section{Marvin Madisa}

ORCID iD: https://orcid.org/0000-0001-7777-4918

\author{
V. Mogonediwa \\ ORCID iD: https://orcid.org/0000-0003-1553-0023
}

Stormburg Vuyile Tiwani

ORCID iD: https://orcid.org/0000-0002-2762-0272

\begin{abstract}
This research focused on personal narratives of four school principals from different school contexts, how they experienced the coronavirus 2019 (COVID-19) crisis and how that experience influenced their leadership. The main question that guided the research, was how these principals made sense of their leadership during the COVID-19 crisis in their different South African contexts.

International and national research confirm that policy implementtation during crisis situations is sometimes compounded by complexities and contradictions such as inappropriate policies, poor leadership and corruption, among other things. The research used a narrative inquiry, in which participants told their stories, to take a fresh look at existing ideas, which in this case is leadership in crisis situations.
\end{abstract}


The research data was analysed within the broad framework of participants' lived experiences, expressed in their different contexts. The reresearch findings confirmed that principals - as departmental officials - must be policy implementers or 'conveyor belts' for the Department of Basic Education (DBE) - though under different contexts of uncertainty, fear and disillusionment during the COVID-19 crisis. This brought many challenges where principals needed to decide whether they should follow their personal feelings and experiences as the school's principal, or blindly obey the departmental creeds.

The significance of these research findings is that a context-based, collaborative and inclusive leadership approach during a crisis - together with availability to modern channels of communication - could be effective.

Keywords: context, COVID-19, crisis, leadership, lived experience, narratives

\section{Introduction}

Principals are accountable for the quality of education in their schools. This does not only refer to the academic performance - normally expressed as a pass rate or some form of quantitative assessment during examinations or tests - but also to the quality of work life and the safety of educators and learners. (The official name for people teaching in a classroom is educators, in the South African context. In the interviews, however, the term teachers will be used since that was the original word that the participants used).) Educators require educational leaders that can provide them with clarity and vision about learning and curriculum requirements, as well as health and safety guidelines in order to define learning solutions that will allow their schools to flourish in times of uncertainty. It may be important that safety and/or health is not officially mentioned as part of the responsibilities and functions of principals, as described in the Personnel Administrative Measures (PAM) (Department of Basic Education (DBE) 2016). With the coronavirus 2019 (COVID-19) pandemic, the safety of learners and all staff members was highlighted; however, since it is primarily expected from principals to implement policies (with the core being on teaching and learning), and to produce examination results, it is deduced that principals 
are not prepared or attuned to monitoring the safety of learners and/or educators. This will be discussed in more detail with the narratives from the specific principals.

The principal's personal experiences and the context in which they function have an important influence on how they personally experience the new COVID-19 challenge; therefore, they may each act differently. This article will focus on the personal narratives of four principals in different contexts to provide a deeper understanding of how they experienced the new challenge - or crisis - and how that influenced their leadership. The article will also contribute towards documenting the history and influence of the novel coronavirus at the beginning of the process - from the South African perspective.

Schools were forced to close in March 2020 without prior notice to principals to prepare for any kind of lengthy closure. The extent of this international pandemic could not have been foreseen by the principals at school level, nor by leadership at national or even international level. It is against this backdrop (of the unprecedented and unknown future that the schools experienced and had to manage), that this article will reflect on the principals in their actual situations.

\section{Problem Statement}

The COVID-19 context, which engulfed the world had a significant influence on the functioning of school leaders. This situation is unique; therefore, it is important to understand how the principals were able to navigate through the initial months of this new phenomenon (Sahlberg 2020). It is not the purpose of this article to argue the label of this phenomenon; however, for the purpose of this article it will be referred to as a crisis ( $\mathrm{Ng}$ 2021). The basic definition of a crisis is 'a stage in a sequence of events at which the trend of all future events, especially for better or for worse, is determined; a turning point; a condition of instability or danger, as in social, economic, political, or international affairs, leading to a decisive change and a dramatic emotional or circumstantial upheaval in a person's life' (https://www.dictionary.com/browse/crisis). This context will further be explored through the narratives of the participants.

South Africa was not the only country to be caught unaware of the implications of the COVID-19 pandemic, which originated in China at the 
end of 2019 (Netolicky 2020; Stone-Johnson \& Weiner 2020). The abruptness of school closures, followed by numerous policies and challenges that principals needed to negotiate, will be followed through the eyes of four principals. They are all experienced and well-qualified principals predominantly from lower socio-economic context schools, which created specific challenges to implement the policies. The human aspect and their own feelings will be explored to indicate their vulnerability in this unknown time (Stone-Johnson \& Weiner 2020). The principals provided their perspectives from both primary and secondary school contexts, as well as no-fee and feepaying schools.

The main research question will therefore be: How did principals make sense of their leadership during the initial stages of the COVID-19 pandemic in the South African context, up to October 2020? The purpose of this article is to provide some insight from the perspective of principals, being unprepared for the immediacy, in March 2020 up to October 2020 which nobody expected at that stage - when the schools were closed.

The outbreak of the COVID-19 pandemic in South Africa in March 2020 necessitated the formulation of numerous policies, which had a bearing on teaching and learning in South African schools. Bayeni and Bhengu (2018:1) contend that complexities and contradictions in policy implementtation are compounded by the fact that the government expects principals and School Governing Bodies (SGBs) to act like 'conveyor belts of its policies'. Furthermore, a number of factors such as a lack of training for human resources, a lack of visionary leadership, inappropriate policies (in the case of COVID-19 specifically due to time constraints), inadequate financial allocation and corruption have been highlighted as some of the reasons for the huge gaps in policy development and their implementation (Bayeni \& Bhengu 2018).

\section{Conceptual Framework}

The conceptual framework for this research focuses on leadership against the backdrop of diversity in South Africa. Special attention is given to leadership during a crisis to determine if there is something that indicates how leaders act and react during a crisis, and this all plays out in a specific context. This context, and the way the leaders reacted to the crisis, will be displayed in the data from the narratives of these principals. With the diversity and challenges 
in the South African society, and therefore also at schools, attempting to achieve social justice - and therefore quality education for all learners - is an important focus for these principals. The COVID-19 context emphasised the differences between schools in low socio-economic contexts, for example informal settlements, and in townships and schools in urban, high socioeconomic areas. The details of the data collected from the participants will be discussed in the narratives.

\section{Leadership during a Crisis}

Principals are expected to act as leaders in their schools - in a specific context - and the COVID-19 pandemic posed a new challenge for them. Leaders need to look after themselves during a crisis: by looking after their own emotions and needs, leaders can be better prepared to handle and assist others (Klann 2020). Klann (2020) suggests the following strategies for leaders to remain calm during a crisis: Leaders must think 'today'; they must focus on the positives; they need to get grounded and they need to prioritise and focus. Binagwaho (2020) wrote in April 2020 (at the beginning of the pandemic when little was known about how leaders were supposed to act) from a medical perspective and indicated that a compassionate leadership approach may be appropriate for this crisis. Harris (2020) suggested that participative and collaborative leadership may be an appropriate approach; however, this was merely a literature review and not based on any empirical data, hence it is not a suggestion based on what actually happened at school level. It is therefore important to identify the leaders' perspective in this article, how they reacted, and which approach they took during the initial phase of the COVID-19 context.

Although AlKnawy (2018) does not write about education per se, he does refer to a situation in 2015, with challenges similar to COVID-19, in a hospital setting. His personal experience is that - in such a crisis - there will most probably be confusion and disturbance, which may have an influence on the level of motivation of the staff members. This kind of crisis requires that the leaders assess the unfamiliar situation as soon as possible, which may require them to take unfamiliar or out-of-the-ordinary actions to ensure the stability of the organisation. The school principals in the research on which this paper is based (but also internationally, since this is an international pandemic) experienced these unusual circumstances of being in a crisis, 
which made it essential for them to remain calm so that they could reduce the level of fear and tension that may arise in their school.

Change is at the heart of leadership, and as agents of change, principals should have a strong participative and collaborative style of leadership while gathering information about needs, conflicting ideas and possible solutions. The change that we experienced in our schools when the COVID-19 crisis started in South Africa, had both external and internal effects, which differed from any other challenges that principals had ever experienced previously. There is no blueprint, or previous experience, for principals relating to a real worldwide pandemic (and there is limited information on which they could base their decisions), which makes decisionmaking and the change process difficult for the leaders and followers. The pandemic exerted external forces as everything had to change quickly starting from the early closure of schools - even before the assessment marks of the first term could be properly captured in the South African School Administration Management System (SA-SAMS). Internal factors including some parents and educators - began to put pressure on the School Management Team (SMT) members to release learners and close the schools as they had 'reliable information' that schools could have closed the previous day due to a potential COVID-19 virus outbreak among learners.

The context of the pandemic, along with its uncertainty, created fear, anxiety and especially a feeling of risk for the principals when the schools had to reopen. According to Lerner and Keltner (2001), it is possible that feelings of fear, anxiety and risk may influence the decisions that leaders make. It is therefore important to understand how the new context - as a potential crisis - may have influenced the decisions of the school principals.

\section{Leadership in and with Context}

An important aspect of this article is the school principal in the specific context. As suggested by Hallinger (2018), it is also considered that context must play a significant role in this study of leadership in education. Although Marishane (2020) did not specifically refer to the COVID-19 context, his reference to contextual intelligence became more important and valuable during the time of the pandemic, and its link with emotional intelligence may be the most important aspect allowing principals to lead within the specific context and uncertainty which was brought by the COVID-19 pandemic. 
There are different ways to understand this relationship: It can be understood from the structure and agency perspective developed by Archer, whose basic 'debate is arguably, the fundamental question regarding the degree of control that individual agents have, to shape their own or some other person's destiny, in contrast to a more structural account which argues that the same individuals are constrained by external factors beyond their control' (Clifton et al. 2013). The COVID-19 context seems to be one where the structure or the outside forces are compelling the agents - in this case the principals - to be reactive rather than be well prepared, due to the suddenness of the pandemic, therefore resulting in a lack of preparedness and policy for these principals.

During this crisis, the principals had to make decisions that are expected of leaders. Since Lerner and Keltner (2001) indicated that personal feelings of anxiety, fear and risk may influence decisions, it is important to note that principals at schools need not make these decisions on their own. The principals had to make decisions that were bureaucratically handed down to them from the top authority in the province, basically implementing the decisions that were already taken at a higher level. Therefore, the personal experiences of fear and anxiety, and later when the schools reopened, the risk, were taken out of their hands.

\section{Social Justice}

The COVID-19 situation also emphasised the diverse socio-economic context in South Africa. The principals, as leaders cannot escape the situation, as this links to the agency and structure approach mentioned above. They are the agents in the context; the structures which are created by the policies they have to work with and the physical structure of the buildings and the socio-economic context in which the schools are located. It is, therefore, possible to indicate that the COVID-19 context emphasised the disparities in social justice as an issue, which still needs attention. The main issues within social justice are: equal opportunity, fairness, equality, legitimacy and welfare (Blackmore 2006; Moral et al. 2020). Ryan (2006) indicated that school leaders must use social justice principles, more than simply focusing on academic achievements, to enable fairness for all learners. In general, but specifically in the South African case, race, socioeconomic level, language and gender issues need greater and more consistent 
attention. Hargreaves (2021) emphasises the important role of the economy and leaders to ensure that during - and specifically after - the pandemic, policy should focus on eradicating the highlighted socio-economic differences. This is an indication of the influence on the divide between the high and low socio-economic contexts, and diversity in many parts of the world that is emphasised by the context of the pandemic. It is also an indication of the lack of reality and context from authors who wrote at the beginning of the pandemic without taking into consideration that a large part of the world has been neglected. Tikly (2011) also mentioned education as a potential roadblock to enable social justice for all. During the COVID-19 context, there have been many demands -and challenges - from teacher unions, learners, political parties and communities at local schools, which emphasised the social justice focus (discussed later in the article). According to Moral et al. (2020: 109), working in schools located in disadvantaged contexts is more difficult than in those placed in advantageous contexts. These disadvantaged schools face socio-economic deprivation with enrolled learners usually from diverse ethnic, cultural and racial backgrounds, with generally low literacy levels. Such schools include learners from families with unemployment challenges, which may be homes led by single-parents, grandparents or even child-headed households which could result in social and economic problems. South African principals experienced similar contextual conditions as Moral et al. (2020) referred to in Spain. This research will indicate how the participants reacted in the specific predominantly deprived - context during the early phase of the COVID-19 pandemic.

\section{Research Design}

The research design followed a narrative inquiry format in which the participants told their stories about their experiences during the initial stages of the COVID-19 context.

A narrative inquiry refers to a specific life experience of the participants. Participants tell the story as they experienced it (Fraenkel et al. 2015). This qualitative approach was used seeing as the context of the COVID-19 is unique, and the narrative inquiry format allows participants to express their feelings and experiences without too many restrictions. Since this research design allows for a large amount of data to be gathered, the 
researchers decided to narrow the focus to ensure that specific aims of the small-scale research could be achieved. The article contributes not only to the development of knowledge but also writes history, since this article, completed in October 2020, is one of the first articles where this unique COVID-19 context is captured from the perspective of principals in South African schools. There have been a few articles that were published internationally; however, these articles in this special edition are the first articles published in journals from the perspective of principals about their first-hand experience of the COVID-19 in South African schools.

The narrative inquiry format provided an in-depth understanding of the feelings and experiences of the specific participants in their unique contexts and interpreted them according to their own personality and history. It also may indicate the development and growth of the individual and/or part of society in a specific context (Moen 2006). The narrative of the participants, in this case, explains the experience, the development and sequence of activities during the unique COVID-19 context. Although leadership - and specifically management - can have a technocratic approach towards policy implementation, this article focuses on the experiences and feelings of the participants and their reaction to this unexpected crisis situation.

\section{Participants}

Since the narrative inquiry requires participants to present personal information, the four participants were purposefully selected from different provinces in South Africa (two provinces, with different districts in the second province) and in different primary and secondary schools. The main author of the article ensured that he knew the principals, thus allowing them to be comfortable enough to express their personal feelings and experiences. The criteria for selection were: principals were experienced and were known to the fifth researcher so that they had sufficient experience of leading the schools over a period of time in difficult circumstances and now in this new crisis situation. The reason for the purposeful sampling was to represent different perspectives. It was also a convenience sample since the participants knew each other, and the main author who assisted in the process through which the participants were willing to share their experiences in narrative form. The three schools in the North West Province were in three different districts and communities. 
Emil Bosch et al.

Table 1: Participants

\begin{tabular}{|c|c|c|c|}
\hline Participant & School & Community & $\begin{array}{c}\text { Experience and } \\
\text { qualifications }\end{array}$ \\
\hline $\mathbf{A}$ & $\begin{array}{l}\text { Primary } \\
\text { school }\end{array}$ & $\begin{array}{l}\text { Quintile 5, lower } \\
\text { middle class with } \\
\text { many learners from } \\
\text { townships and } \\
\text { squatter camps. }\end{array}$ & $\begin{array}{l}\text { First undergraduate } \\
\text { education degree, } 38 \\
\text { years' experience in } \\
\text { education, and four } \\
\text { years as principal at } \\
\text { the current school in } \\
\text { the Western Cape. }\end{array}$ \\
\hline B & $\begin{array}{l}\text { Primary } \\
\text { school }\end{array}$ & $\begin{array}{l}\text { Quintile 2, low } \\
\text { socio-economic } \\
\text { area. }\end{array}$ & $\begin{array}{l}\text { Doctoral degree in } \\
\text { education leadership, } \\
33 \text { years' education } \\
\text { experience, and nine } \\
\text { years as principal in } \\
\text { the current school in } \\
\text { North West Province. }\end{array}$ \\
\hline $\bar{C}$ & $\begin{array}{l}\text { Secondary } \\
\text { school }\end{array}$ & $\begin{array}{l}\text { Quintile } 1 \text {, a new } \\
\text { school with } \\
\text { minimum facilities, } \\
\text { in an informal } \\
\text { settlement. }\end{array}$ & $\begin{array}{l}\text { Doctoral degree in } \\
\text { education leadership, } \\
33 \text { years of education } \\
\text { experience, one year } \\
\text { as acting principal at } \\
\text { the new school and } 20 \\
\text { years as principal in a } \\
\text { secondary school in } \\
\text { North West Province. }\end{array}$ \\
\hline D & $\begin{array}{l}\text { Secondary } \\
\text { school }\end{array}$ & $\begin{array}{l}\text { Quintile } 2 \text { and in a } \\
\text { fast-growing } \\
\text { township } \\
\text { surrounded by rural } \\
\text { areas. }\end{array}$ & $\begin{array}{l}\text { Master's degree in } \\
\text { education leadership, } \\
22 \text { years of experience } \\
\text { as principal, and six } \\
\text { years at the current } \\
\text { school in North West } \\
\text { province. }\end{array}$ \\
\hline
\end{tabular}




\section{Participant A (PA)}

Per Table 1, he has been a principal at his current primary school for four years and has a degree and teacher qualification. He has been working in the educational system for 38 years. Most of the learners are from lower-tomiddle class areas; however, many of the learners also hail from extremely poor townships and informal settlements. The school is categorised as a quintile 5 school (a fee-paying school in the higher socio-economic areas of the country). It does not have a national feeding scheme, as most of the learners come from homes where there is a steady, albeit small monthly income. The school is a high-functioning school according to the annually Systemic Testing of Grades 3 and 6 . The results for both these grades range from between $86 \%$ and $94.7 \%$. The school has 422 learners enrolled from Grade 1 to Grade 7, a staff complement of 31 which is made up of the principal, 20 educators (11 paid from SGB funds), six cleaners (four paid from SGB funds), three administration assistants (two paid from SGB funds) and 1 general assistant (paid from SGB funds).

\section{Participant B (PB)}

He started his education career 33 years ago and holds a doctoral degree in education management. He has been the principal of a primary school in the North-West Province since 2011, which is in a township. The school is in an area that is ravaged by high levels of poverty and the catchment area is threeroomed houses, hostel residences-turned family units, government-built Reconstruction and Development Programme (RDP) houses (small houses which replaced the tin shacks) as well as informal settlements of the township whose children choose isiXhosa as their Home Language. Many of the learners' parents are unemployed; some of whom have just been retrenched from their jobs because of the deteriorating economic situation in the country. The school is in quintile 2, and therefore a no-fee school (parents are not obligated to pay school fees), with 1216 learners enrolled from Grade R to Grade 7 . The school has a staff complement of 42, which is made up of 35 educators, three cleaners, two administrative assistants and two general assistants.

\section{Participant C (PC)}

He is currently the principal of a new secondary school that opened on $15^{\text {th }}$ 
January 2020, in the North-West Province. At the beginning of the 2020 academic year, he requested to pioneer a new school since it resolved the problem of too many learners at his previous school. By the end of January 2020, the new school had one volunteering administration assistant, nine educators (including the principal) and 240 learners from Grades 8 to 10 . The school caters for learners providing for English home language teaching and learning, as this was a serious need in the area. This area is currently undergoing development, roads are being constructed and electricity infrastructure is being installed. There are no houses yet but residents have erected shacks as dwelling places. Many community members are unemployed. From time to time the community members embark on protests, demanding to be employed by construction companies. During one of these protests, the community barricaded the entrance to the schoolyard. This is a quintile 1 school, which is among the $20 \%$ of schools in the lowest socio-economic context in the country.

The principal holds a doctoral degree in education management; he started his teaching career in 1987 and was appointed as the principal of a primary school in 1999. In 2000, he was appointed as the principal of a secondary school. This secondary school had 1200 learners, 38 educators, two administration staff members and two general assistants. The school was classified as a low performing school, but this low performance improved in the first year with him as the principal. In the 2019 Grade 12 results, the school achieved a $93 \%$ pass rate. This is a quintile 2 school.

\section{Participant D (PD)}

He was appointed as a principal in 1999 and is now at his third school as principal. He holds a master's degree in education management and is currently busy with his doctoral studies in education management. The secondary school is located in the North West Province in a fast-growing township and is surrounded by rural areas. The school is a quintile 2 school. The learner enrolment stands at 1 160, with an educator complement of 35, the principal included. There are 16 support staff members, who comprise one administration assistant, one general assistant, six food handlers, four cleaners, two screeners and two security guards. The school is doing extremely well academically and achieved a $92.1 \%$ pass rate in the 2019 Grade 12 National Senior Certificate examinations. 


\section{Data Gathering}

The data gathering process was initiated through informal discussions with between one of the researchers and several participants about the influence of COVID-19 on leadership in schools, from March 2020. The official data gathering - which is presented in this article - started after ethics clearance was completed at the North-West University. The data gathering process and purpose were discussed with the four selected participants and once they agreed to the process, the official data gathering commenced. After the process and purpose of a narrative inquiry format were discussed with the participants, the participants wrote their experiences in a broad framework, which was agreed upon to enable the participants to structure their feelings. This was done purposefully, since without any framework the narratives may have been too wide with many different perspectives, but the framework was not descriptive and only served as guidelines.

The broad framework which the participants could use focused on their personal and professional experiences, the change process and the best interests of the children, which included social justice issues before as well as during the crisis with a focus on the gap between policy and policy implementation. The participants were requested to focus on their own feelings and emotions, for example, stress and anxiety levels, to indicate their frame of mind. The leading participant (Heystek)ensured that the questions were not leading, in the sense that they did not telling the participant what to say but rather helped them in a self-reflective manner to understand their own situation and feelings and remember certain aspects that were not clear in the initial narrative.

The focus of the article is to understand the experience and the reactions of the participants. Therefore, it was agreed on guidelines for the focus of their narratives. After the initial reflective narratives were written, different meetings (some were telephonic discussions while others were WhatsApp discussions or email discussions) were convened where the participants could discuss their narratives with each other and reflect on what they had written. The participants shared their written narratives with the other participants so that each participant could ask questions and make comments to enhance the depth and understanding of their own narrative. One of the researchers led the writing process by asking more specific questions in shorter interviews with the participants to clarify and get further 


\section{Emil Bosch et al.}

detail on certain aspects of the narratives.

A final discussion with the participants was conducted for them to read the draft of the article (data checking) which contributed to the trustworthiness of the data. This meeting also helped them to clarify that the narratives were authentic and not too bound by the initial structure for the narratives, Further, the discussion helped to identify if the participants had experiences any negative effects, for which necessary help and support could be arranged.

\section{Data Analysis and Trustworthiness}

The data was analysed within the broad framework that was presented to the participants (Silverman 2014). The main categories were therefore already in place and were used to understand the participants' experience within the specific categories. The categories did not limit the participants; how and what they wanted to tell and therefore within the broad categories they had the freedom to express themselves and tell the narratives as they experienced them.

An inductive approach was followed with the analysis of the data (De Vos et al. 2016); the emphasis was on the experience and expressions of the participants. Although there are many theories about leadership, and the influence of sociological and psychological processes on individuals and groups, the researchers analysed the data with an open mind to see how and what the participants expressed in the narratives.

It is important to note that the analysis, interpretations and conclusions of the data are credible; in other words, the readers believe and understand what is presented to them (Silverman 2014). The researcher, in collaboration with the participants, developed a broad framework for the narratives to prevent them from being too broad and diverse. The framework helped the participants to have some focus but still, their own narrative style and personality were more important. Therefore, the framework was a broad guideline, not intended to restrict their personal experience. The data presented are the ideas and words of the participants and the researcher is merely presenting their perspectives without interfering with their perspectives. The purpose is to express the lived experience, and therefore how they interpret and understand it differs from person to person and therefore an attempt is made to give a realistic perspective from the 
experience of the participants during this time. It is difficult to determine the reliability (Silverman 2014) since reliability implies that if similar research is conducted, similar results will be obtained. However, with a narrative inquiry format it may not find the similar results with other selected participants. Another narrative inquiry format may not find the same results, since personal experiences - based on life history - and personality have an important influence. Reliability in this research was considered by the researcher, and the relationship that was built between the researcher and the participants allowing them to be open about their experience and the leadership and the trust level between the researcher and the participants must therefore be the most important issue to establish reliability. The purpose of the research was not to find the truth or a similar perspective; the purpose was to gather data on the lived experiences of the participants; the interpretation of which may lead to a better understanding of the challenges of leaders in a totally new context for which they may have never had any training.

\section{Ethics}

The information in this article is part of a broader project concerning leadership in the COVID-19 context. The project received ethical clearance from the North-West University as well as the personal informed consent from the participants. Since the participants were individually selected and volunteered to participate, they do not officially represent the different provincial departments.

\section{Leading in Different Contexts}

\section{Announcing a Crisis and Principal's Reactions}

The World Health Organization (WHO) declared the COVID-19 situation as a pandemic on 11th March 2020. The announcement by the president of the Republic of South Africa, on 15th March 2020, set the country on a hard lockdown from 26th March 2020.

Participant D indicated that,

I had to rely on social media platforms like WhatsApp and Facebook 
to communicate with our learners and parents since we couldn't assemble at school for fear of the transmission, and the spread of the virus amongst ourselves. This mode of communication proved to be difficult and expensive because some parents and learners couldn't afford the costs of data, and some were not in possession of the appropriate gadgets to receive the information. Not all parents and learners could be reached during the period of the total lockdown, which added to my frustration and anxiety as a principal. I felt helpless, lonely and sometimes useless because I couldn't perform as I was used to. About $70 \%$ of parents could not be reached and as a result, missed out on the information shared through these platforms.

Participant A stated that,

Subsequent to President Ramaphosa's national address on Sunday evening, $15^{\text {th }}$ March, my communication to the parents of our learners that same evening, sent via the D6 Communicator (our official and weekly means of communicating with parents through email and SMS) made it very clear to them that we value the physical wellbeing of our learners and that there would be no punitive measures taken should they elect to keep their children at home. All this communication was shared electronically. All our parents have access to a cell phone and have previously downloaded the D6 app[lication], in order to receive communication from the school.

Participant A stated,

This was the beginning of a period of uncertainty, frustration and anxiety not only for everyone involved with the school - but also, and especially, for me.

In 2020, school principals are [were] having to manage hitherto unimaginably high levels of stress and whether one wants to acknowledge it or not, it was beginning to take its toll.

Participant C, supported by Participant A, expressed the confusion he experienced, 
Another frustrating problem was the two dates of school closure. The National Minister of the Department of Basic Education had made an announcement in the media that schools were to close on 17 th March 2020 (Tuesday), whilst the notice from the Superintendent General in the North-West indicated that schools would close on 18th March 2020 (Wednesday). This created confusion whereby other schools closed on 17th March 2020. The WhatsApp messages from the sub-district manager that were sent to clarify the above misunderstanding were of little help. Some learners and parents had followed what they captured from the media. In my letter of 17 th March 2020 to parents I had indicated that schools would close on 18th March 2020, but it had little effect because a few learners did not pitch up for [attend] school on the $18^{\text {th }}$ [March 2020]. This letter was given to learners present at the school on 17th March 2020. Eventually, some learners missed out on some of the subjects that were rescheduled for 18th March 2020.

The educational leadership, and in this situation the minister at national and provincial levels, had to act in the face of this new phenomenon. There were more uncertainties about the extent of the virus, but still, it was expected that there must be leadership and guidance. This culminated in new policies and processes from national and provincial levels, which needed to be enacted by the principals at schools.

At face value, that COVID-19 had been declared a pandemic it could be expected that a first human instinct would be to flee from the invisible disease. In the opinion of Participant $\mathrm{A}$, the provincial department acted opposite to this natural human instinct by demanding that the staff members must remain at schools until 20th March 2020 although it had been announced that the schools were closing on 18th March 2020.

One may then surmise that the focus of the department was on the avoidance of ramifications concerning learner infections and/or fatalities, and not on the protection of its employees at schools. Participant A, with agreement from Participant $\mathrm{C}$, further stated that,

The educators, administrative staff and support staff were all extremely anxious about, not only their own physical wellbeing but also those of others at [their] home[s]. 


\section{Schools Open}

The closure of the schools lasted longer than expected. The announcement that schools would reopen on 1st June 2020 and that educators and support staff were to attend work prior to that date to prepare the school, and themselves, was another challenge for the principals. The Standard Operating Procedures (SOPs) were one of the numerous policies, procedures and rules that the principals referred to during this process of schools opening (DBE 2020a).

Participant A remarked that, 'Initially, on the $18^{\text {th }}$ May 2020, the educators were very subdued and their anxiety was almost tangible'.

Participant B said,

The first two weeks of school reopening for teachers (in preparation for the phased-in return of learners) was stressful, as I had to deal with a number of issues such as putting up markings (of up to $1.5 \mathrm{~m}$ ) for social distancing in [on] the pavement that leads to our school main entrance, in the staffroom and in the classes.

Confusion was exacerbated when the Minister of Basic Education, Ms Angie Motshekga, changed the date that schools would reopen from alreadygazetted 1st June 2020 to 8th June 2020 because 'not all schools were ready'.

Participant $\mathrm{C}$ experienced that,

The confusion for teachers emanated from conflicting statements made by the national department and the teacher unions about the readiness of schools to resume teaching and learning. I assured the teachers that we had to follow what the education department was directing. However, this was almost impossible because teachers are unionised, including the new ones. They went with what the teacher unions pronounced on the readiness of schools. I could sense a lot of fear for their lives amongst the teachers. The majority of them were young, had just started teaching and clearly inexperienced. Therefore, they panicked a lot.

New and inexperienced educators were particularly concerned about their professional futures. Participant $\mathrm{C}$ said the following, 
Although all the eight teachers showed anxiety and uncertainty about their future, the novices needed a lot of reassurance. These five new teachers had [just] started working this year, having completed their studies in 2019. They kept asking me about their future, [with questions such as] will they receive their salaries, how long will schools remain closed?

Participant A stated that in his opinion the department, without expert guidance from the WHO, intent on avoiding any recriminations, started the unwieldy process of flooding schools with documents that, hopefully, would safeguard learners against COVID-19. 'It should be noted that the focus was on safeguarding learners, not educators'.

According to the opinion of Participant $\mathrm{C}$ above, it seems as if the unions protected the educators and that it is understandable if the principals may have been caught in the middle between the unions and the department. Participant D felt that the situation,

Leads to untold frustration and anxiety in myself as a principal and leader of my institution. These feelings of frustration and anxiety went on to affect other members of the SMT (School Management Team), the SGB (School Governing Body), staff, (both professional and support), learners, as well as the community, given the time we lose due to cleaning and sanitation for the actual teaching and learning in the classroom, as they look up to me for proper advice and guidance during these difficult times.

Further to this, Participant B experienced a lack of proper communication from different levels in the provincial department and stated that,

the confusion that came with the implementation of the above regulations [SOPs] nearly exposed me to a number of condemnations for poor leadership in a number of areas, such as the appointment of screeners and cleaners, the enforcement of social distancing, the school readiness for the staggered phasing in of other grades and dealing with teachers with comorbidities. This was indeed frustrating as teachers, learners and senior officials expected the school to operate normally in this unusual situation, with the principal providing leadership. 


\section{Emil Bosch et al.}

With the Department of Basic Education issuing directives with the intent of reopening schools while exhibiting a total disregard for the safety of educators, participant B point out the following:

Some of our school teachers would literally show fear when a learner comes [came] to school coughing or with 'flu [influenza] symptoms or has [had] returned from a family member's funeral.

Participant $\mathrm{C}$ addresses this by questioning the department's handling of the COVID-19 context:

My feeling was that there should have been a better way of addressing anxiety issues first. Moreover, teaching and learning cannot happen effectively in an environment engulfed by apprehension and suspicion of who is the carrier of the virus. These anxiety issues were left for principals as school leaders to handle, and to me, this was not a good practice of leadership. I was personally insufficiently prepared to deal with teachers, learners and parent anxiety. I had to 'dig deep' to ensure that I did not show any uneasiness myself. I felt that the Department of Basic Education was not exercising good leadership. They just put pressure on schools to resume.

Participant D stated,

My school had five educators and one Grade 12 learner infected with the disease. The learner knew of her status after she consulted [her doctor] for flu [influenza], and the parents informed me. I was scared for my life since I had interacted with most of the educators and those who were still awaiting their results were also frightened.

The participants all experienced varying levels of increased stress during the onset of COVID-19. Participant A felt strongly about the DBE's lack of empathy, especially after one of the educators tested positive for COVID-19:

Disillusioned by those issuing directives from comfortable and safe abodes, while those in the front ranks were left to face dangers. The analogy of a conventional war springs to mind, with troops risking 
their lives in the trenches, while those who could, but chose not to protect and assist them, 'fought' the 'war' from their safe and comfortable offices hundreds, [a] thousand kilometres away.

Participant D said the following,

Though WHO had indicated that the disease is not severe in children when they are infected, the opposite has proved to be true for (some) schools, because some of the learners experienced a combination of COVID-19 symptoms that left them, their families, their classmates and the entire school community extremely traumatised. This also traumatised me, given the interaction I have with my learners from time to time. My engagements with some of the parents regarding the safety of our establishment against this disease also tested my leadership because I had to put [on] a brave face and assure every parent that we were on top of the situation as an institution.

Participant $\mathrm{C}$ indicated that:

When it came to teachers, I had to maintain a brave face and portray confidence that the ascending infection rates will [would] not last forever. I had to gather as much information as possible about the spread of COVID-19. This, at least, put me at ease to stand confidently in front of the teachers. I believed that, if I could win the confidence of the teachers to come to school, I would have won half the battle.

Participant B stated:

Having been a principal for nine years, the COVID-19 crisis brought about uncertainty in me personally, and also as the school principal. I was gaining my teachers' confidence as someone who they can [could] run to for guidance about work and personal issues, their doubts about their service in the department [DBE] as well as general motivation to continue teaching for the sustainment of our school's legacy. However, such trust constantly dwindled as I would receive the department's directives from some of them, being my subor- 
Emil Bosch et al.

dinates who have contacts in well-placed positions of the department.

The virus was still with us at the time of writing in October 2020, and we now understood it a little better than earlier in the year. On a daily basis we are learning how to better avoid being infected, and when infected, how to be better equipped physically, emotionally and intellectually as to how to deal with it and we are also learning how to live with it being all around us. It is not less virulent and it is not harmless, yet we need not fear it as intensely as we did in late March 2020, when we had almost no knowledge about it.

\section{Leading during a Crisis: A Social Justice Issue}

Three of the participating principals are from schools in low socio-economic and disadvantaged communities, while the fourth principal has a fair number of learners from similarly low socio-economic context in the school; therefore most of the issues that are recorded as social justice issues are applicable for the schools in this study. The social justice issues are due to a lack of communication due to poor electricity or internet connections - or available funding to the school facilities where the buildings are not large enough to allow for sufficient social distancing - as well as a lack of funding for the school. Three of the four participating schools are no-fee schools; hence their budget is very limited.

Participant $\mathrm{C}$ argued,

What frustrated me [the] most was that we were in the process of writing quarterly tests. We were totally unprepared for the directive to close earlier. The availability, and unavailability of school resources, whether financial, human or material resources, proved to be an impediment in implementing policies such as the SOPs as well as the ELRC (Education Labour Relations Council) Resolution 1 of 2020. (Author: it refers to the teachers with comorbidities).

The participants in the study commented that it was very difficult to operate in such communities during the COVID-19 crisis. In terms of social justice, participants stated the following. 
It is at this point that the plan should look at recovery and returning things to a new normal. An important question becomes: what happens if another crisis hits again? This requires the principal to develop a crisis plan as well as to set resources aside. However, setting sufficient resources aside would be difficult as schools had to spend resources on unexpected activities due to the pandemic.

Participant A stated,

The downside of this exercise was that it cost the school more than R 8000.00 to have it decontaminated.

Although Participant A's school is a quintile five school, and in a relatively good socio-economic context, it is important to recognise that there are diverse compositions of learners in many schools. It may even be more difficult for similar schools to have sufficient funding since although they are classified as a quintile five school with a high income expected, they are influenced by the percentage of learners from low socio-economic context. These learners may not be able to pay all - or any - of their school fees, which can make it difficult for such a school to live up to the students' expectations of small classes because more teachers could be appointed from the additional school fees, since funding may become a problem. He therefore further commented: 'Many of our learners also hail from extremely poor areas'. Participant D supported this, saying 'Most of the learners attached to my school are from impoverished background[s] and the establishment is on [in] quintile 2'.

Participant B also worked with destitute communities,

Our school is in an area that is ravaged by high poverty levels, our catchment area being three-roomed houses, hostel residences-turned into family units, government-built 'RDP' houses as well as informal settlements of the township ....

Participant C commented further regarding inequality,

Furthermore, I thought it would be unfair on some parents, especially 
those with low literacy levels. In my view, such parents would struggle to assist learners with the work that the latter (the parents) would find difficult to understand. I saw inequality showing its ugly face. Once more I felt very frustrated that our learners were at a disadvantage, as many of them come from a low socio-economic society where unemployment and poverty are visible to the naked eye.

Participant D indicated the disadvantage they faced since no-fee schools with limited funding find it difficult to appoint additional academic all-support staff, while fee-paying schools in higher socio-economic areas, may have additional funds because the school fees may make provision for some additional expenses.

We had to use part of our Section 21 funds (fees that are normally allocated for academic purposes such as purchasing textbooks or other urgent needs) to fumigate the school every time most of these cases emerged. We did not benefit from the COVID-19 funds that were so much talked about, and as a result, we had to run around a lot purchasing COVID-19 compliant necessities we did not budget for.

Participant D further indicated the challenges of schools in low socioeconomic context,

There are still many outstanding issues that haven't been attended to by the DBE in an attempt to assist schools to successfully fight this pandemic, such as [the] availability of water, renovation of broken/ vandalised and burnt schools, as well as the provision of schools with substitute educators, especially those affected by comorbidities. It's like the more things change, the more they remain the same. In as much as we have to live side by side with this virus, schools, as extensions of various households, have to be given more than ample support to continue their fight against this pandemic for the ultimate benefit of the broader community.

The above comments suggest that it was difficult for principals to ensure the 
fulfilment of social justice in the schools they worked in, because of the unequal socio-economic circumstances. Teaching and learning suffered because some schools had to adopt a rotational model whereby learners attended on alternating days, whilst other schools resorted to a platoon system whereby some learners attended in the morning and others in the afternoon. The comments further indicate that South Africa may be one of the most unequal societies in the world, and it would be cumbersome to practise or achieve social justice. Furthermore, the comments indicate that COVID-19 did well to expose the gap of inequality, because many former model $\mathrm{C}$ schools managed to continue with schooling for all grades simultaneously.

\section{Policy Implementation and the Policy Gap}

Since the closure of schools in March 2020, the principals and educators were inundated with new policies, rules and procedures; for example, SOPs for educators, non-teaching staff and learners on the COVID-19 outbreak, the amended 2020 school calendar for public schools, National Circulars S2 and S3 of 2020 (Department of Basic education 2020c and 2020d) as well as the Revised National Teaching Plans for 2020 (Department of Basic education 2020e).

The policies dealt with in this section are not all existing policies but are examples of new policies to indicate the influence they had on the principals and their practice. Participant A reflected on dealing with information during the pandemic, saying:

This was the beginning of a period filled [full] to overflowing with COVID-19-related documents and directives...The uncertainty and frustration that characterise the next two or three months may well remain with numerous principals - myself included - for quite some time. Forms 'to be completed urgently' (often identical ones) were sent through from different WCED (Western Cape Education Department) offices, as well as from head office, on different days of the week (and) it was frustrating to be castigated for not responding to a circular/newsletter that is an almost exact duplicate of an earlier one but having one change made to the document.

Participant $\mathrm{C}$ observed the uncertainty, 
The confusion for teachers emanated from conflicting statements made by the education department and teacher unions. I could sense a lot of fear for their lives.

\section{(i) Appointment of Screeners, Cleaners in Compliance to Standard Operating Procedures (DBE 2020a)}

In terms of the SOPs (DBE 2020a: 10), schools should maintain high standards of hygiene, conduct daily screening of visitors by using a checklist (consisting of six questions) and take individuals' temperatures.

Participant $\mathrm{B}$ convened a meeting with the SGB after receiving a Circular dated 20th May 2020, via WhatsApp from the district, stating that the school must appoint two cleaners, for a 10-month period, and 10 unemployed youths, for a once-off deep cleaning of the school, to be paid for by the Provincial Department. Schools received an amount of R8 000.00 for cleaning the school, which includes the cleaning material as well as the payment of the people. Participant A - in another province - confirmed that they received the same amount for the cleaning, but that it was not sufficient. Participant B selected and appointed screeners and cleaners with the support of the SGB and the ward member for the specific area of the community. The local community - and especially the young people - were angry about this and confronted the principal and the ward member, because they felt that they were not considered for the positions.

Participant B said,

The young people literally confronted me immediately after the ward counsellor had finished addressing them, demanding to know why I had allowed the ward committee to do the appointments as they (the ward committee) are - and have always been - biased towards them, favouring instead young people from other sections of the ward. I rescued myself by promising to consider them when other opportunities became available. ...After this encounter, I had mixed feelings. First, I felt scared (as many young people in this area belong to a group of gangsters notoriously known as 'Crazy Dogs'), and then I felt humiliated (as the young people insinuated that those employed secured their employment after visiting my house and those of the ward committee members). 
Participant $\mathrm{C}$ experienced similar problems in another part of this province,

When posts were advertised for screeners and cleaners in schools, the community blocked the entrance to the school gate. They emphasised that Extension 9 was their territory, therefore no one outside of Extension 9 should be employed at the school.

Participant D indicated the challenges with the implementation of the policy,

The situation dictated that unpopular decisions, for example, the appointment of screeners and cleaners, had to be made given the speed at which this virus was spreading. The guidelines for these processes only came later, but the first round was in the hands of the principal. There was also some confusion since the (Provincial) department appointed people to be cleaners and screeners, while it was also expected that the principals must appoint people for the same posts and positions.

The provision of personal protective equipment (PPE), before the schools opened in June 2020, was problematic since there were financial and other challenges with the delivery and provision to schools. Schools had to use their own funds for sanitation, otherwise the schools had to close. This created problems, especially for the quintile one, two and three schools with limited budgets.

Participant D indicated that,

Since the investigation on PPEs for corruption was started (about September 2020), the provincial department (of education) decided to discourage schools from fumigating their premises whenever a COVID-19 case emerged. From the approximately R1.9 million allocated to the school (for 2020), half will be reserved for stationery and textbooks (for 2021), which leaves our school with R950 000.00. We have, by the end of June, used approximately R55 000.00 for COVID-19 compliant necessities. We were instructed to use Jik [bleach], Domestos [bleach] and [alcoholbased] sanitisers for fumigation purposes. 
Emil Bosch et al.

Participant A - in another province - indicated that there were no problems at that stage with the corruption and that they had enough PPE, but they would have to pay for PPE in 2021.

The situation is further aggravated as indicated by Participant D,

This made me very angry since I had to risk the lives of our cleaners by exposing them to the use of the detergents that have never been tested before in the fight against this unknown enemy, should a COVID-19 case emerge... This puts my leadership to a serious test given that as a representative of the Head of Provincial Department (HOD) in the SGB, I had to come in from time to time and convince them that the department does care, and we shall overcome.

Complying with the implementation of policies and procedures has become more complicated as indicated by participant $\mathrm{D}$,

Contrary to the directives of the HOD, regarding disinfecting and/or fumigation of the premises, by using Jik [bleach], Domestos [bleach] and [alcohol-based] sanitiser, whenever a COVID-19 case rears its head, the SOP dictates that we should have a deep-cleaning service provider on call in case of an emergency, which added to my confusion as a leader and principal of my secondary school (DBE 2020a clause 2.10).

\section{ii) Enforcing Social Distancing in Line with Standard Operating Procedures (DBE 2020a)}

Section 5.1.1 of the SOPs (DBE 2020: 12) requires that learners, educators, support staff, officials, parents and community members should ensure that a distance of $1.5 \mathrm{~m}$ to $2 \mathrm{~m}$ is maintained between people, as a way of preventing person-to-person infections.

Participant A said:

In order to honour the $1.5 \mathrm{~m}$ social distancing stipulation, desks in classrooms were moved further apart; some [were] even removed and stored in order to effect the necessary change. 
A challenge, specifically for the quintile 1, 2 and 3 schools whose facilities are not as good as the quintile 4 and 5 schools, was explained by Participant B. The principal and educators discussed the relevance of the $1.5 \mathrm{~m}$ social distancing between desks, which translated into 10 learners per class when using double desks, in our case, instead of single desks. This meant that for our 143 Grade 7 learners (which were normally using four classrooms of 43 learners each, which is more than the official number indicated by the national Department of Basic Education), we would need 14 classes. This would have led to a shortage of classrooms when all the other grades were to be phased in.

Participant B maintained,

I contacted a departmental official; however, he provided no solution but instead urged the principal to improvise. This was indeed frustrating as educators, learners and senior officials expected the school to operate normally in this unusual situation, with the principal providing leadership.

My school was visited by a high ranking official in the department to monitor the school about its readiness to phase in the first group of learners (Grade 7) on 8th June 2020. On her arrival, she declared that we were not ready in terms of compliance with 1.5 $\mathrm{m}$ social distancing per [each student in] class.

Yes, as the principal I took the blame for not adhering to the SOPs (2020a: 2) regulations of social distancing when setting desks in the classes. This was because as a school we did not have single desks which would have allowed us to comply and have 20 learners in a class instead of 10 learners.

Participant D's school was visited by the Minister of Education, Mrs Angie Motshekga on 04th August 2020 to check on COVID-19 compliance and the re-opening of classes for the Grade 12 learners after recess. Although she was impressed with their efforts to abide by the COVID-19 regulations, her visit was nearly spoiled by a group called PSM (Progressive Students' Movement), when she was about to leave the school. On the other hand, the minister's visit motivated both the Grade 12 learners and educators to look 
at the academic year positively and believe that regardless of a very poor start due to the pandemic, the school could perform exceptionally well at the end. 'The visit also motivated me and made me proud as a leader and principal of my establishment'.

Participant $\mathrm{C}$ indicated that the social distancing had staff implications, which the Provincial Department of Education did not deal with properly:

Social distancing guidelines that were issued by the Basic Education Department require that learner numbers in one classroom should be restricted to 20 . However, this was not followed properly in terms of the appointment of additional teachers. No permission was granted to the school to appoint teachers where shortages emerged due to social distancing requirements.

\section{(iii) School Readiness Monitoring to Enforce the Revised School Calendar for School Re-opening}

The monitoring instrument used to monitor school's readiness to open on 8th June 2020 after closing abruptly on 18th March 2020 brought about a great deal of confusion. It sought to address genuine issues such as whether the principal had oriented educators, parents, SGB, learners and general workers about the COVID-19 pandemic; assess whether the school had enough PPE for all stakeholders; ascertain whether there were any plans for educators to monitor social distancing of learners in the morning, during breaks, during playtime and to determine whether letters had been written to the parents about their roles in taking precautionary measures before they sent their children to school.

The situation has since relaxed, with social distancing no longer monitored and enforced as was done before, educators are less strict in their monitoring routines during breaks, and learners are sometimes allowed to walk around the school with their cloth masks in their pockets or school bags. Ironically, the monitoring instrument was new to principals and SMTs as they had never been informed about what to prepare for school reopening except for the instruction that required principals to employ screeners and cleaners four days before educators were to report for duty (21st May 2020). The details of how to screen, what to observe in people and learners, how to use the thermometer and the actual checklist for screening people were never 
provided to the newly appointed screeners. The departmental official observed that principals were neither orientated nor familiar with the language of her monitoring instrument, such as the revision of the school budget in line with COVID-19 regulations, maintaining a plan for the management of social distancing as well as convening SGB, and parents' meetings while under strict lockdown regulations. A departmental official further declared that schools were non-compliant in the decision to have 20 learners in a class, and instead instructed there to be only 10 learners in a class. This instruction demoralised the entire staff who had previously requested the principal's approval on the number of learners per class.

Participant A observed that in his province, there were contradictions in the implementation of the revised school calendar for schools reopening by the provincial education department.

Participant A argued,

According to the original school calendar issued by the DBE, the closing of schools, at the end of the first term, was to be 20th March, but, although President Ramaphosa stated that learners would end their first term on 18th March, [the] WCED stated in no uncertain terms that staff (should) remain at school until Friday $20^{\text {th }}$ of March 2020 Not every learner honoured the call of the DBE to return to school on the staggered phased-in dates provided per grade in line with the revised school calendar for 2020 (DBE 2020).

Participant $\mathrm{C}$ further observed:

For example, we had 42 grade 10 learners when we closed the school in March 2020 due to lockdown restrictions. But since the reopening of schools, it has only been 25 who attended. This represented a $40.4 \%$ dropout rate. This dropout [rate] worried me a lot. I have learnt with dismay that some would no longer be coming back. I was not sure of the exact reasons for this high dropout rate, but the information I had gathered from teachers and learners indicated, inter alia, that some learners were pregnant, some just staying at home, some had lost hope and believed that they would not pass and one was arrested. 
Emil Bosch et al.

Even during the initial closure of schools, there were gaps in implementing the directives of the DBE.

\section{(iv) Educators with Comorbidities in Line with ELRC Collective Agreement No. 1 of 2020}

The ELRC resolution 1 of 2020 (ELRC 2020: 1) provides for a concession process that should be followed for employees that are employed in terms of the Employment of Educators Act 76 of 1998 who have underlying medical conditions, or comorbidities that put them at risk of contracting COVID-19. Section 4.1 of resolution 1 of 2020 (ELRC 2020: 3) further directs principals, or managers, to complete the risk assessment form for every employee who indicated that they have an underlying condition or comorbidity, and for them to remain at home on full pay whilst awaiting the outcome by the health risk manager or a health professional.

Participant B indicated that,

On receipt of this resolution, posted on WhatsApp by one principal who serves in the provincial structures of the South African Democratic Teachers' Union (SADTU), I informed my colleagues during our briefing session and requested those who believe that they have underlying medical conditions to consult their doctors and present to me the medical certificates that confirm the doctors' findings. Out of a total of 35 educators, twelve brought medical certificates declaring that they have medical conditions that put them at risk. However, only seven of them [the twelve] declared that they would be working from home in line with section 4.1 of the resolution.

Participant D argued that,

15 of my professional staff members - myself included - have comorbidities in one form or another but couldn't qualify for the concessions (special arrangement for working from home).

Participant D said his school was the first in the cluster after the schools opened in June to feel the effects of this disease, given that four of his male professional staff members, and one female, as well as one girl learner in 
Grade 12 were infected with the deadly novel coronavirus. Participant D indicated that:

As a principal, I found myself between a rock and a hard place based on the conflicting messages I received from my seniors in relation to how effectively and efficiently I could delay the rapid spread and transmission of the disease amongst educators, learners and the broader community .... I had to give people hope where there was none, considering the negative impact that this disease had already had in [on] all of us.

Participant $\mathrm{C}$ contended that,

Teachers with comorbidities had to work from home, but this was unclear to me. What exactly would these teachers be doing, and how?

On the $5^{\text {th }}$ June 2020 , in another district, an urgent meeting of circuit principals, attended by district officials resolved to recall educators with comorbidities who were working from home as the health risk manager had not yet made approvals. This was in sharp contrast to the ELRC resolution 1 of 2020 . We were preparing to welcome the first group of learners, Grade 7s, on 8th June 2020. Our SMT requested the district office of the Department of Health to provide clarity about staff members with comorbidities, because they were confused by the principals' report on a meeting he attended, and what is contained in section 4.1 of ELRC Resolution 1 of 2020.

Participant B reflected on these meetings as follows:

The health officials confronted the sub-district manager and to my surprise, the blame was put on me. I was instructed to communicate with the teachers so that they can go back to their homes as the resolution prescribes. I felt I was made a scapegoat; however, I diligently took the blame.

Such contradictions created mistrust and antagonism between the principal as the main player in implementing policies of the department - and the 
educators, whose role is to comply with what the principal authorises them to do as a policy implementer of the DBE.

\section{Conclusion}

The participants in this project exhibited leadership in circumstances for which they had never been prepared. Although there are no official training or developmental requirements - or opportunities - for principals, three of the participating principals completed postgraduate qualifications. That may have been a good background, and in some or another way may have prepared them for the unknown, since postgraduate studies were also something, they had encountered for the first time (perhaps a form of crisis?) and had to do it on their own with limited support except for their official study leader, and perhaps close friends and/or family.

The narratives of these participants must therefore also be understood within their own personal context and background (habitus), since few principals will pursue postgraduate studies and still be a successful principal. All the participants are experienced principals, which may also contribute to their actions and ability to lead in this new crisis.

There have been limited differences between the principals' experiences - even from the different communities' context. The only real difference was that at school A the principal had more access to parents and the community because a large part of the community had more access to technology, such as the internet. Since this school also had a huge diversity in terms of where the learners come from, it also provided more challenges. There is a part of the community expected to be able to continue with schooling since they have the facilities while the other part of the school community had to be taken into consideration since they do not have the electronic facilities. The principals in the same province, but in different districts, had similar personal experiences and the communities had similar challenges as highlighted in the examples. All the principals experienced similar levels of stress and challenges with the closing and reopening of the schools even while they were in different provinces, in different contexts and circumstances. The personal experiences are therefore equal to their own personal backgrounds as highly qualified and experienced principals.

The principals are in complex and challenging circumstances since they are representing the provincial head of department, and therefore, must 
comply with the rules and regulations. However, they are also human beings; they experienced feelings of fear, sadness, anger and they had to put on brave faces, even if they were not certain and afraid. The principals were to a certain extent in a protected decision-making bubble where they just had to implement the decisions, for example about the social distancing in the school or when to open the schools. They experienced stress and anxiety and sometimes anger because of the practical problems with the implementation, for example with the distancing aspect. However, the decision had already been made and the principals only needed to implement it. It could have been worse, and a much more difficult situation to make decisions if each school were left to its own devices in terms of decision-making about how, and when, to open the schools. There is only one public example of a principal who did not want to open the school again, and that principal has since been charged by the Department of Education in the Western Cape (Mlamla 2020).

Although none of the study participants tested positive for the novel coronavirus, educators and learners in their schools who were positive; therefore they felt they were confronted with the virus often and had to make decisions because of their position as a principal. They had to do as they were instructed - or expected - despite their personal experience with the virus, which they seemed to face daily. A case where the principal did not comply with the departmental rules and regulations, is still ongoing in the Western Cape where a principal has been charged for not implementing and obeying the rules of the department (Siyo 2020). Thus, the participants were all aware of this kind of interaction and had to toil with the duality; to be an obedient servant of the state and their own and community needs, which they experienced first-hand at the ground level.

There is specific evidence of the differences between provinces emphasising the social justice issues in the education system of the country. Although this is a small case study - and cannot be generalised - it was evident that in the Western Cape, the school had more opportunities (with electronic communication and better facilities) than the schools in the North West Province. Principals are expected to perform at equal levels of effectiveness to one another, despite the challenges and differences with infrastructure and funding. These narratives indicated that it is difficult for these principals, but their personality and experience may be an important factor in their success to lead in new and unexpected circumstances. 
The context, or structure, has an influence on the participants, for example during the appointment of the cleaners and screeners. The participants in the same province had both the same information and specifically lack of information at the beginning of the appointment of the cleaners and screeners. They dealt with it in different ways with the context determining some of these actions, for example in one case the ward member reduced the number of people appointed, which was not prescribed by policy but the local context had that influence. The specific participant had to comply with the local context and then deal with the consequences. It is therefore evident that context can sometimes overrule the official policy, and the leader at the ground level has to make a decision and later take the responsibility for it.

The participants also indicated that they were and remained, caught between the demands and priorities from the national and provincial department on one side, and the teacher unions on the other side. The departments prioritised the completion of the curriculum, while the unions were prioritysing the educators and the safety (specifically before the schools opened again in June), which led to personal conflict for the participants. The principals had to obey the orders from the department but the educators in the school were also departmental officials and had to abide by these rules. The situation - and 'leading in the context'- have changed significantly since March, and specifically when the schools started in June until the current situation at the completion of the article in October 2020, as indicated by Participant B:

We are now more relaxed, no longer worried or concerned about learners congregating in groups during break times. We even allow learners to go and buy lunch from our nearby tuckshop (although they still remain inside the schoolyard but buy through the fence). We are no longer as emotional as before, even though we are cautious around each other by wearing masks, practise social distancing and sanitise after every twenty minutes. As a school we are not as fearful as we were before, however, the approach that we have adopted is an inclusive one in which we share information and collaborate in the fight against this common enemy.

People and leaders are adaptable, they are able to cope and manage the con- 
text and situation, and what has been seen as a serious crisis about six months ago has since become normal. This form of human activity and adaptation requires more detailed research to understand how leaders adapt to real, challenging situations.

A final reflection on leadership and personality is concluded by Participant A as follows:

My management style has always been one of engaging people and I believe that one can manage without being draconian. Being firm (a Laissez-Faire approach to leadership is destructive), yet kind and compassionate, win hands down and even those who initially prefer the dictatorial style of management (perhaps it could be seen as affording them security?) eventually begin to realise the value of self-growth. It is a slow process, however.

Has my style of leadership changed because of COVID-19? Further to the above, I wish to add that it did, as such, not change, for I have to remain true to who I am. I do believe, however, that I have become a stronger leader within the context of my particular style of leadership. This I have come to realise engenders more trust in my leading of the staff and has also provided me with increased confidence in my ability to guide, lead and support. Adversity more than often edifies.

Recommendations are that there must be more research on leadership in this context, and specifically on principals from different professional and personal backgrounds, which can assist in understanding how much the personal characteristics and the context will play a role in leading into new and challenging crises or contexts.

\section{References}

AlKnawy, B. 2018. Leadership in Times of Crisis. BMJ Leader 3:1 - 5. https://doi.org/10.1136/leader-2018-000100

Bayeni, S.D. \& T.T. Bhengu 2018. Complexities and Contradictions in Policy Implementations: Lived Experiences of Three School Principals. SAGE Open 1 - 12. https://doi.org/10.1177/2158244018792037 
Emil Bosch et al.

Binagwaho, A. 2020. We Need Compassionate Leadership Management Based on Evidence to Defeat COVID-19. International Journal Health Policy Management 9, 10: 413 - 414.

https://doi.org/10.34172/ijhpm.2020.73 PMCid:PMC7719216

Blackmore, J. 2006. Deconstructing Diversity Discourses in the Field of Educational Management and Leadership. Educational Management Administration \& Leadership 34,2: 181 - 199.

https://doi.org/10.1177/1741143206062492

Clifton, A., J. Repper, D. Banks \& J. Remnant 2013. Co-producing Social Inclusion: The Structure/ Agency Conundrum. Journal of Psychiatric and Mental Health Nursing 20: 514 - 524.

https://doi.org/10.1111/j.1365-2850.2012.01953.x

PMid:22882808

Department of Basic Education (South Africa) 2016. Personnel Administrative Measures. Consolidation of the Terms and Conditions of Employment of Educators Determined in Terms of Section 4 of the Employment of Educators Act 1998. https://www.naptosa.org.za/docmanager/30-labour-matter/archived/920-pam/file

(Accessed 28 October 2020.)

Department of Basic Education (South Africa) 2020a. Standard Operating Procedures for Teachers, Non-teaching Staff and Learners in the Coronavirus (2019-ncov) or COVID-19 Outbreak in South Africa. (September version.)

https://www.education.gov.za/Portals/0/Documents/Recovery\%20plan \%20page/Links\%20for\%20schools/dbe-standard-operating-procedurefor-covid-19.pdf?ver=2020-10-21-111244-020

(Accessed on 28 October 2020.)

Department of Basic Education (South Africa) 2020b. The Protocol on the writing of preparatory examinations under the covid-19 environment, Pretoria: Government Printers.

Department of Basic Education (South Africa) 2020c. Release of the revised annual teaching plans (atps) for grade 7 and grade 12 respectively. CIRCULAR S2 OF 2020.

https://www.education.gov.za/Portals/0/Documents/Recovery\%20plan \%20page/Links\%20for\%20schools/circular-s2-2020-curriculum-

recovery.pdf?ver=2020-06-15-091313-790

(Accessed 28 October 2020.) 
Department of Basic Education (South Africa) 2020d. Distribution of the teacher guidelines for the implementation of annual teaching plans (ATPs) and the minimum core content and skills per subject and per grade. CIRCULAR S3 OF 2020.

https://www.education.gov.za/Portals/0/Documents/Publications/Circu lar\%20S3\%20of\%202020\%20-

\%20Distribution\%20of\%20Teacher\%20Guidelines.pdf?ver=2020-0721-160352-163 (Accessed 28 October 2020.)

Department of Basic Education (South Africa) 2020e. Recovery Plan. https://www.education.gov.za/Home/RecoveryPlan2020.aspx (Accessed on 28 October 2020.)

De Vos, A.S., H. Strydom, C.B. Fouche \& C.S.L. Delport 2016. Research at Grassroots. For the Social Sciences and Human Service Professions. Pretoria: Van Schaik.

Fraenkel, J.R., N.E. Wallen \& H.H. Hyun 2015. How to Design and Evaluate Research in Education. New York: McGraw-Hill.

Hallinger, P. 2018. Bringing Context Out of the Shadows of Leadership. Educational Management Administration \& Leadership 46,1: 5 - 24.

https://doi.org/10.1177/1741143216670652

Hargreaves, A. 2021. Austerity and Inequality; Or Prosperity for All? Educational Policy Directions beyond the Pandemic. Educational Research for Policy and Practice 20,1: 3 - 10.

https://doi.org/10.1007/s10671-020-09283-5

PMCid:PMC7711614

Harris, A. 2020. COVID-19 - School Leadership in Crisis? Journal of Professional Capital and Community 5,3/4: 321 - 326.

https://doi.org/10.1108/JPCC-06-2020-0045

Klann, G. 2020. How to Lead through a Crisis. Centre for Creative

Leadership. https://www.ccl.org/articles/leading-effectively-

articles/how-to-lead-through-a-crisis/ (Accessed on 27 October 2020.)

Lerner, J.S. \& D. Keltner 2001. Fear, Anger and Risk. Journal of Personality and Social Psychology 81,1: 146 - 159.

https://doi.org/10.1037/0022-3514.81.1.146

PMid:11474720

Marishane, R.N. 2020. Contextual Intelligence in School Leadership.

Leiden: Brill, Sense. https://doi.org/10.1163/9789004431263

Mlamla, S. 2020. Heathfield High School Principal Granted Temporary 
Emil Bosch et al.

Interdict in WCED Clash. 5 October 2020.

https://www.iol.co.za/capeargus/news/heathfield-high-school-

principal-granted-temporary-interdict-in-wced-clash-658f69ab-b1a0-

4d8d-bc41-63d393176640

Moen, M. 2006. Reflections on the Narrative Research Approach.

International Journal of Qualitative Methods 5,4: 56 - 69.

https://doi.org/10.1177/160940690600500405

Moral, C., L. Higueras-Rodríguez, A. Martín-Romera, E. Martínez-Valdivia \& A. Morales-Ocaña. 2020. Effective practices in Leadership for Social Justice - Evolution of Successful Secondary School Principalship in Disadvantaged Contexts. International Journal of Leadership in Education 23,2: 107 - 130.

https://doi.org/10.1080/13603124.2018.1562100

Netolicky, D.M. 2020. School Leadership during a Pandemic: Navigating Tensions. Journal of Professional Capital and Community 5,3/4: 391 395. https://doi.org/10.1108/JPCC-05-2020-0017

Ng, P.T. 2021. Timely Change and Timeless Constants: COVID-19 and Educational Change in Singapore. Educational Research for Policy and Practice 20,1: 19 - 27. https://doi.org/10.1007/s10671-020-09285-3

PMCid:PMC7610234

Ryan, J. 2006. Inclusive Leadership and Social Justice for Schools. Leadership and Policy in Schools 5,1: 3 - 17. https://doi.org/10.1080/15700760500483995

Sahlberg, P. 2020. Will the Pandemic Change Schools? Journal of Professional Capital and Community 5,3/4: 359 - 365.

https://doi.org/10.1108/JPCC-05-2020-0026

Siyo, A. 2020. More Support for Under-fire Principal who Refused to Reopen School during COVID-19 Peak. 5 October 2020.

https://www.iol.co.za/capetimes/news/more-support-for-under-fireprincipal-who-refused-to-re-open-school-during-covid-19-peaka2f525cd-7291-495b-86e8-0c218dc1a60c

(Accessed 5 October 2020.)

Silverman, D. 2014. Interpreting Qualitative Data. Los Angeles: Sage.

Stone-Johnson, C. \& J.M. Weiner 2020. Principal Professionalism in the Time of COVID-19. Journal of Professional Capital and Community 5,3/4: 367 - 374, 2056 - 9548.

https://doi.org/10.1108/JPCC-05-2020-0020 
Tikly, L. 2011. A Roadblock to Social Justice? An Analysis and Critique of the South African Education Roadmap. International Journal of Educational Development 31: 86 - 94.

https://doi.org/10.1016/j.ijedudev.2010.06.008

Principal Emil Bosch Western Cape bosch@icloud.com

Professor Jan Heystek Edu-Lead Research Faculty of Education North West University Potchefstroom jan.heystek@nwu.ac.za

Principal Marvin Madisa Gauteng mmadisa.mm@gmail.com

Principal V. Mogonediwa

North West Province vicmaiketso@gmail.com

Principal Stormburg Vuyile Tiwani North West Province svtiwani@hotmail.com 